\title{
DETERMINATION OF DIMENSIONAL AND SHAPE PARAMETERS OF CROSS-SECTIONS OF NATURAL TORRENTS IN SMALL MOUNTAIN WATERSHEDS
}

\author{
Matúš Jakubis ${ }^{1}$, Mariana Jakubisová2 \\ ${ }^{1}$ Department of Forest Harvesting, Logistics and Amelioration, Faculty of Forestry, Technical University in Zvolen, \\ T. G. Masaryka 24, 96001 Zvolen, Slovak Republic \\ ${ }^{2}$ The Borova Hora Arboretum of the Technical University in Zvolen, Borovianska cesta 66, 96001 Zvolen, Slovak \\ Republic
}

Link to this article: https://doi.org/10.11118/actaun.2021.053

Received: 5. 8. 2021, Accepted: 21. 10. 2021

To cite this article: JAKUBIS MATÚŠ, JAKUBISOVÁ MARIANA. 2021. Determination of Dimensional and Shape Parameters of CRoss-sections of Natural Torrents in Small Mountain Watersheds. Acta Universitatis Agriculturae et Silviculturae Mendelianae Brunensis, 69(5): 595-603.

\begin{abstract}
The aim of this article is to assess the accuracy of estimates of geometric and shape parameters in cross-sections of natural mountain torrents using the equations of regional downstream hydraulic geometry. Equations of regional hydraulic geometry were derived for 19 natural torrents of the Western Tatras in the geomorphological unit of the Tatras. The equations for the relations between the watershed area $\mathrm{A}_{\mathrm{w}}\left(\mathrm{km}^{2}\right)$ and the bankfull channel width inside the banks $\mathrm{B}_{\mathrm{bf}}(\mathrm{m})$, channel depth $H_{b f}(m)$, channel cross-section area $A_{b f}\left(m^{2}\right)$ and shape characteristics of the cross-section $B_{b f}: H_{b f}$ and $H_{b f}: B_{b f}$, were ascertained. At the same time, equations for the relationships between the length of the main stream $\mathrm{L}_{\mathrm{r}}(\mathrm{km})$ and aforementioned dimensional and shape parameters were derived. Subsequently, the measured geometric and shape parameters of the natural cross sections of torrents were compared with the calculated values. Differences between measured and calculated characteristics were found and confirmed by pairwise selection testing.
\end{abstract}

Keywords: bankfull geometric characteristics, hydraulic geometry, torrent morphogenesis

\section{INTRODUCTION}

Observations of the hydraulic geometry of streams are widely used in fluvial geomorphological research and watercourse management. The results of research involving regional hydraulic geometry provide important information for torrent control designing, revitalization and watersheds management. In this context, we refer specially to the design of such dimensional and shape characteristics of cross-sections, that are close to nature. Powel et al. (2004) indicates that in the USA regional equations of hydraulic geometry are used in the designing and revitalization of watercourses. Howell (2009) suggests that regional hydraulic curves are especially useful in stream restoration projects, where the stream is so degraded that natural bankfull channel geometry can no longer be determined and no reference thereto is available. Regional curves can be used also in projects such as road, bridge and culvert construction. Wilkerson (2008) states that these informations are essential for planners, engineers, geomorphologists, environmentalists, agricultural interests, developments situated on flood-prone lands, and others interested in floods and flooding. Regional curves should be applied only to projects within the same geographic region or in a region that features the same hydraulic geometry curves (Howell, 2009). Wilkerson (2008) noted that a physiographic region is a region in which 
all parts are similar in geologic structure and climate, which has a unified geomorphic history and where its relief features differ significantly from those of adjacent regions. Regional equations represent relationships between geomorphologic and hydrologic characteristics of watershed and geometric and hydraulic characteristics of channel profile. There are two types of channel and watershed regional equations which are based on the theory of hydraulic geometry: 1) at - a - station with variations at a particular cross-section and 2) downstream with variations along the length of the watercourse (Julien, 2014). On the other hand, predictions concerning the development of watercourse beds and a determination of geometric and shape characteristics of their cross sections by means of hydraulic geometry equations may be characterized by a certain variability and uncertainty. The longitudinal variability in hydraulic geometry along a reach has received little attention in research literature. Harman et al. (2008) state that ariations in hydraulic geometry observed at sites in a given region over time are often assumed to be true variation, but measurement uncertainty may also contribute to these variations. Stewardson (2005) states that the flow profiles selected for measurement may be unrepresentative of the watercourses in which they are located. Rosgen (1994) dealt in detail with the issue of channel shapes in natural watercourses; the author states that the width/depth ratio describes the dimension and shape factor as the ratio of bankfull channel width to bankfull mean depth. The shape characteristics of natural riverbeds in connection with their development has been discussed by Osterkamp et al. (1983), Montgomery and Buffington (1997), Montgomery and Gran (2001),
Finnegan et al. (2005), Milar (2005), Vianello and D’Agostino (2007), Thornton et al. (2007), Beechie et al. (2008), David et al. (2010), Kemp (2010), Agouridis et al. (2011), Buffington and Montgomery (2013), Latapie et al. (2014), Aisuebeogun, Ezekwe (2014), Whitbread et al. (2015), Choi et al. (2015), Allen et al. (2018), Ohara, Yamatani (2019).

\section{MATERIALS AND METHODS}

Analyzed torrents and watersheds are located in the Tatras National Park (TNP) in the geomorphological unit of Tatry, the subunit of Západné Tatry (Fig. 1) at altitudes from 690 to $2248 \mathrm{~m}$ a.s.l. The eastern border of the Western Tatras is formed by the Kôprovský torrent. The right section of the Kôprovský torrent watershed (in the direction of the flow) is already a part of the High Tatras. The highest point of this watershed is the Kriváň hill (2494 m a.s.l.).

Nineteen torrents with enclosing crosssections near the southern border of TNP (located in proximity to the northern border of the geomorphological unit of Podtatranská kotlina) were analyzed. Analyzed torrents are situated in the main river watershed Váh. The watershed areas of 19 analyzed torrents range from $\mathrm{A}_{\mathrm{w}}=1.20 \mathrm{~km}^{2}$ (Klinovaté) to $\mathrm{A}_{\mathrm{w}}=54.61 \mathrm{~km}^{2}$ (Tichý) with the median of $\tilde{A}_{w}=10.14 \mathrm{~km}^{2}$. The $Q_{100}$ discharges range from $\mathrm{Q}_{100}=4.4 \mathrm{~m}^{3} / \mathrm{s}$ (Klinovaté) to $\mathrm{Q}_{100}=150 \mathrm{~m}^{3} / \mathrm{s}$ (Tichý) with the median of $\bar{Q}_{100}=27 \mathrm{~m}^{3} / \mathrm{s}$. The streams of Western Tatras are typical mountain torrents with frequent and rapid changes in discharges, sediments formation, transport of these sediments and their accumulation. Geological structure of the analyzed area is variable. Magmatic rocks predominate in the analyzed area: biotite tonalites to granodiorites,

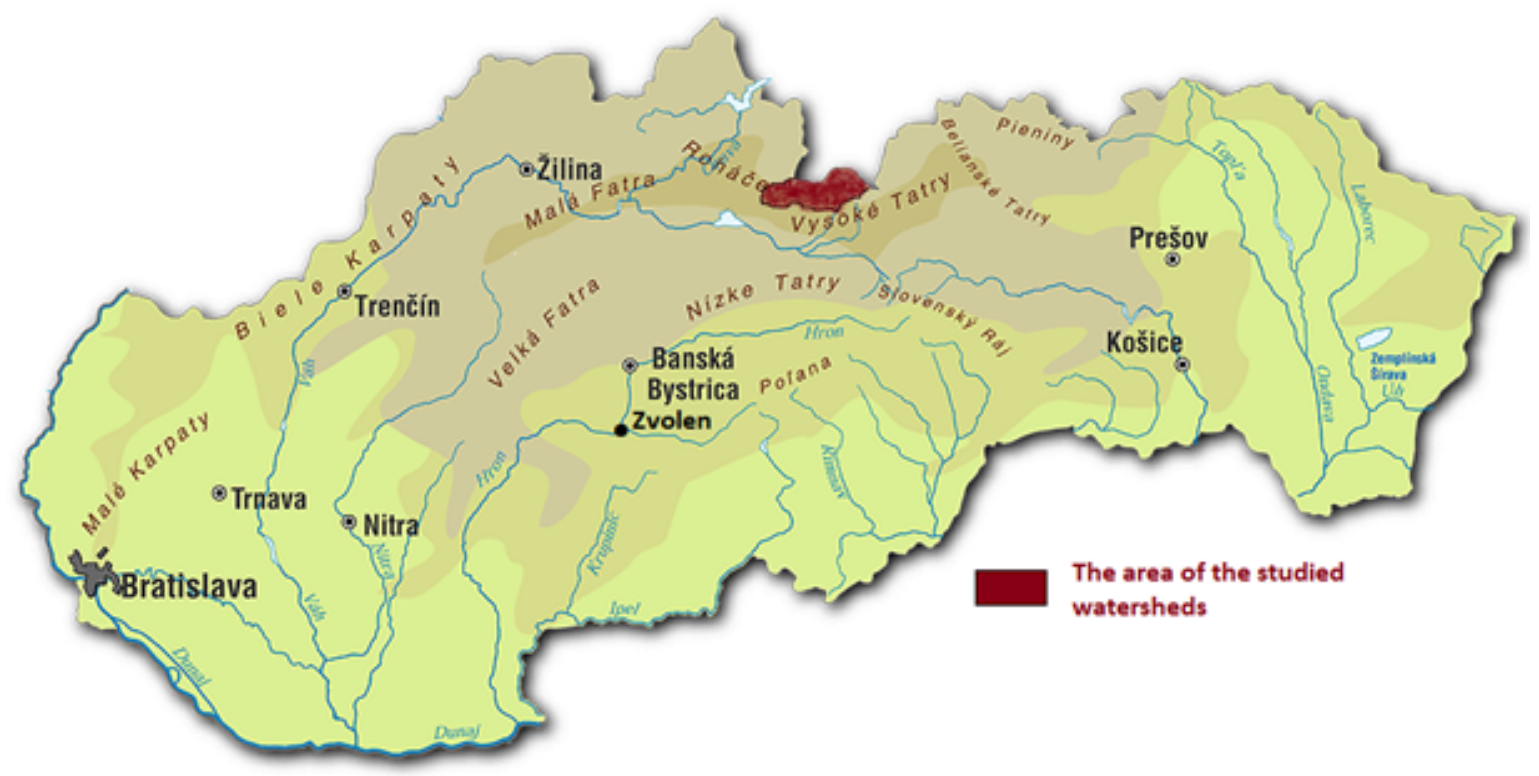

1: Map of Slovakia with the research area (Western Tatras) 
locally porphyritic. The further occurances here include porphyritic granodiorites to granites and leucocrate granitic rocks. As for soil types, in higher elevations Lithic Leptosols and other (nonrendzic) Leptosols are dominant; in the middle parts of the watersheds the most frequently occuring types are Cambic Podzols and Haplic Podzols. In lower position occur Dystric Cambisols, Cambic Umbrisols and Stagni-Dystric Cambisols. From the aspect of hydrological efficiency the soils in the higher watershed positions have high retention capacity with medium permeability and moderate retention capacity and permeability in the lower elevations (Ministry of Environment of the SR, 2002). The watersheds (by the climatic regions of the Slovak Republic) are located in climatic region $\mathrm{C}$ - cold with the subregions: $\mathrm{C} 1$ - moderately cool, $\mathrm{C} 2$ - cool mountainous and C3 - cold mountainous (Ministry of Environment of the SR, 2002, 2002). Average annual precipitation in the watersheds ranges from $1132 \mathrm{~mm}$ (Suchý) to $1612 \mathrm{~mm}$ (Kôprový). Average annual temperatures in watersheds range from $0.19^{\circ} \mathrm{C}$ (Kôprový) to $3.48^{\circ} \mathrm{C}$ (Suchý). Climatic data were derived from the data of five measuring stations of Slovak Hydrometeorological Institute in the region of the Western Tatras for the years 19612010.
In this case the samples are the set of natural cross-sectional geometric characteristics from which the hydraulic geometry of the entire torrent network is ascertained. The watercourses in Tatras region generally have three characteristics zones: 1) zone with sediment formations (zone of erosion), 2) zone of sediment transport (transport zone) and 3) sediment deposition zone. Boundaries between these zones can not be determined precisely, they vary depending on discharge and other factors. The shape of natural torrent beds in each zones also varies and is predominantly influenced by the shape of the valley. In the highest sections of the torrents, the cross-sections have a V-shape. In the middle part the profiles are U-shaped and in the lower part are broad U-shaped (Jakubis, 2000; Jakubis and Jakubisová, 2019, 2020).

On straight stretches of each natural torrents without human interventions under the erosion zone, we selected the reference longitudinal sections (RLS) with reference cross-sections (RCS) and determined their bankfull geometric and hydraulic characteristics according Page (1988) and Rosgen (1994, 2009). RLS were selected in the torrents so as to capture well the overall character of the torrent over a longer section. Subsequently, we chose RCS to represent the character of RLS

I: Basic geometric and hydraulic characteristics of RCS

\begin{tabular}{|c|c|c|c|c|c|c|c|c|c|}
\hline Torrent & $\begin{array}{c}\mathrm{A}_{\mathrm{w}} \\
\left(\mathrm{km}^{2}\right)\end{array}$ & $\begin{array}{c}\varphi \mathrm{H}_{\mathrm{w}} \\
\text { (m a.s.l.) }\end{array}$ & $\begin{array}{l}\mathrm{B}_{\mathrm{bf}} \\
(\mathrm{m}) \\
\end{array}$ & $\begin{array}{l}\mathrm{H}_{\mathrm{bf}} \\
(\mathrm{m})\end{array}$ & $\begin{array}{c}A_{b f} \\
\left(m^{2}\right)\end{array}$ & $\begin{array}{c}\mathrm{S} \\
(\mathrm{m} / \mathrm{m}) \\
\end{array}$ & $\begin{array}{l}\mathrm{R}_{\mathrm{bf}} \\
(\mathrm{m}) \\
\end{array}$ & $\begin{array}{l}\mathrm{O}_{\mathrm{bf}} \\
(\mathrm{m}) \\
\end{array}$ & $\begin{array}{c}\mathrm{Q}_{\mathrm{bf}} \\
\left(\mathrm{m}^{3} / \mathrm{s}\right)\end{array}$ \\
\hline Suchý & 17.7 & 1247 & 10.1 & 1.00 & 8.3 & 1.52 & 0.814 & 10.2 & 13.42 \\
\hline Studená & 3.2 & 1146 & 3.4 & 0.65 & 1.85 & 2.24 & 0.487 & 3.8 & 2.06 \\
\hline Jalovský & 22.33 & 1487 & 11.0 & 1.05 & 9.8 & 1.29 & 0.860 & 11.4 & 16.25 \\
\hline Rakytie & 3.06 & 1384 & 3.2 & 0.60 & 1.65 & 2.42 & 0.458 & 3.6 & 1.75 \\
\hline Krivý & 2.48 & 1401 & 3.0 & 0.50 & 1.4 & 2.41 & 0.424 & 3.3 & 1.40 \\
\hline Vrbička & 2.05 & 1411 & 2.9 & 0.45 & 1.15 & 2.69 & 0.371 & 3.1 & 1.04 \\
\hline Smrečianka & 17.99 & 1543 & 9.9 & 1.00 & 8.2 & 1.37 & 0.796 & 10.3 & 12.85 \\
\hline Trnovec & 4.55 & 1540 & 5.5 & 0.70 & 3.1 & 2.01 & 0.492 & 6.3 & 3.42 \\
\hline Kobylie & 1.88 & 1444 & 2.9 & 0.50 & 1.3 & 2.12 & 0.394 & 3.3 & 1.12 \\
\hline Kamenná & 2.13 & 1410 & 3.1 & 0.60 & 1.4 & 2.77 & 0.400 & 3.5 & 1.35 \\
\hline Klinovaté & 1.20 & 1260 & 2.3 & 0.40 & 0.8 & 2.51 & 0.333 & 2.4 & 0.45 \\
\hline Račková & 35.76 & 1572 & 13.7 & 1.20 & 15.8 & 0.91 & 1.033 & 15.3 & 29.27 \\
\hline Jamnícky & 18.75 & 1576 & 11.7 & 1.15 & 11.2 & 1.31 & 0.903 & 12.4 & 19.38 \\
\hline Krivul'a & 14.46 & 1467 & 7.7 & 0.85 & 5.4 & 1.06 & 0.651 & 8.3 & 6.94 \\
\hline Bystrá & 10.22 & 1549 & 6.9 & 0.80 & 4.8 & 1.45 & 0.649 & 7.4 & 6.40 \\
\hline Surový & 5.15 & 1338 & 4.0 & 0.60 & 2.0 & 1.49 & 0.465 & 4.3 & 2.66 \\
\hline Kamenistý & 10.14 & 1571 & 7.5 & 0.90 & 5.8 & 2.03 & 0.707 & 8.2 & 8.63 \\
\hline Tichý & 54.61 & 1639 & 19.7 & 1.50 & 26.5 & 1.07 & 1.318 & 20.1 & 61.30 \\
\hline Kôprový & 30.47 & 1573 & 15.0 & 1.35 & 18.6 & 1.38 & 1.148 & 16.2 & 39.52 \\
\hline
\end{tabular}

$\mathrm{A}_{\mathrm{w}}$ : watershed area; $\varphi \mathrm{H}_{w}$ : mean altitude of the watershed; $\mathrm{B}_{\mathrm{bf}}$ : width of the RCS inside the banks; $\mathrm{H}_{\mathrm{bf}}$ : depth of the RCS; $\mathrm{A}_{\mathrm{bf}}$ : RCS area; $S$ : energy gradient; $\mathrm{R}_{\mathrm{bf}}$ : hydraulic radius of RCS; $\mathrm{O}_{\mathrm{bf}}:$ wetted perimeter; $\mathrm{Q}_{\mathrm{bf}}$ : bankfull discharge. 
well. We chose the reference profiles under the erosion zones so that they would not be unduly affected from the sides by the slopes of the valley. The geometric characteristics of the RCS were measured by leveling. The basic characteristics of watersheds, along with the geometric characteristic of RCS: width of the bed inside the banks $B_{b f}(\mathrm{~m})$, channel depth $H_{b f}(\mathrm{~m})$, cross-sectional area $A_{b f}\left(\mathrm{~m}^{2}\right)$ with the medians of $B_{b f}=6.90(\mathrm{~m}), H_{b f}=0.80(\mathrm{~m})$, $A_{b f}=4.80\left(\mathrm{~m}^{2}\right)$ are listed in Tab. I. Bankfull discharge $Q_{b f}\left(\mathrm{~m}^{3} \cdot \mathrm{s}^{-1}\right)$ with the median of $Q_{b f}=6.40\left(\mathrm{~m}^{3} \cdot \mathrm{s}^{-1}\right)$ was calculated by Jarrett's equation (Rico et al., 2001) in the form:

$Q_{b f}=3.17 A_{b f} \times R_{b f}^{0.83} \times \mathrm{S}^{0.12}\left(\mathrm{~m}^{3} \cdot \mathrm{S}^{-1}\right)$

where:

$\mathrm{A}_{\mathrm{bf}}$.....cross-sectional area $\left(\mathrm{m}^{2}\right)$;

$\mathrm{R}_{\mathrm{bf}} \ldots .$. hydraulic radius (m),

$S$........energy gradient of RCS $(\mathrm{m} / \mathrm{m})$.

The values of $\mathrm{B}_{\mathrm{bf}}: \mathrm{H}_{\mathrm{bf}}$ and $\mathrm{H}_{\mathrm{bf}}: \mathrm{B}_{\mathrm{bf}}$ ratios and morphological characteristics of the watersheds are given in Tab. II.

\section{RESULTS AND DISCUSSION}

The derived equations of regional hydraulic geometry are given in Tab. III. According to these equations, geometric $\left(\mathrm{A}_{\mathrm{bf}}, \mathrm{B}_{\mathrm{bf}}, \mathrm{H}_{\mathrm{bf}}\right)$ and shape characteristics $\left(\mathrm{B}_{\mathrm{bf}}: \mathrm{H}_{\mathrm{bf}}, \mathrm{H}_{\mathrm{bf}}: \mathrm{B}_{\mathrm{bf}}\right)$ for all of RCS were calculated. Due to the large amount of data, we present in Tab. IV. only the average values of deviations between the measured data and the data calculated according to the equations in Tab. III. A graphical representation of the curves of the individual relations are shown in Fig. 2 to Fig. 5. By analyzing the obtained results, we found that estimates of the geometric characteristics of crosssections based on the equations of downstreram hydraulic geometry may not be accurate. By comparing the measured values of $\mathrm{B}_{\mathrm{bf}}(\mathrm{m}), \mathrm{H}_{\mathrm{bf}}(\mathrm{m})$, $\mathrm{A}_{\mathrm{bf}}\left(\mathrm{m}^{2}\right)$ and ratios $\mathrm{B}_{\mathrm{bf}}: \mathrm{H}_{\mathrm{bf}}$ and $\mathrm{H}_{\mathrm{bf}}: \mathrm{B}_{\mathrm{bf}}$ with the calculated values using the regional equations of hydraulic geometry (Tab. III), certain differences were found to occur. We used the pairwise selection method for testing and then calculated the difference for each pair comparison. Subsequently, we found the arithmetic mean and standard

II: Shape characteristics of RCS and characteristics of watersheds and torrents

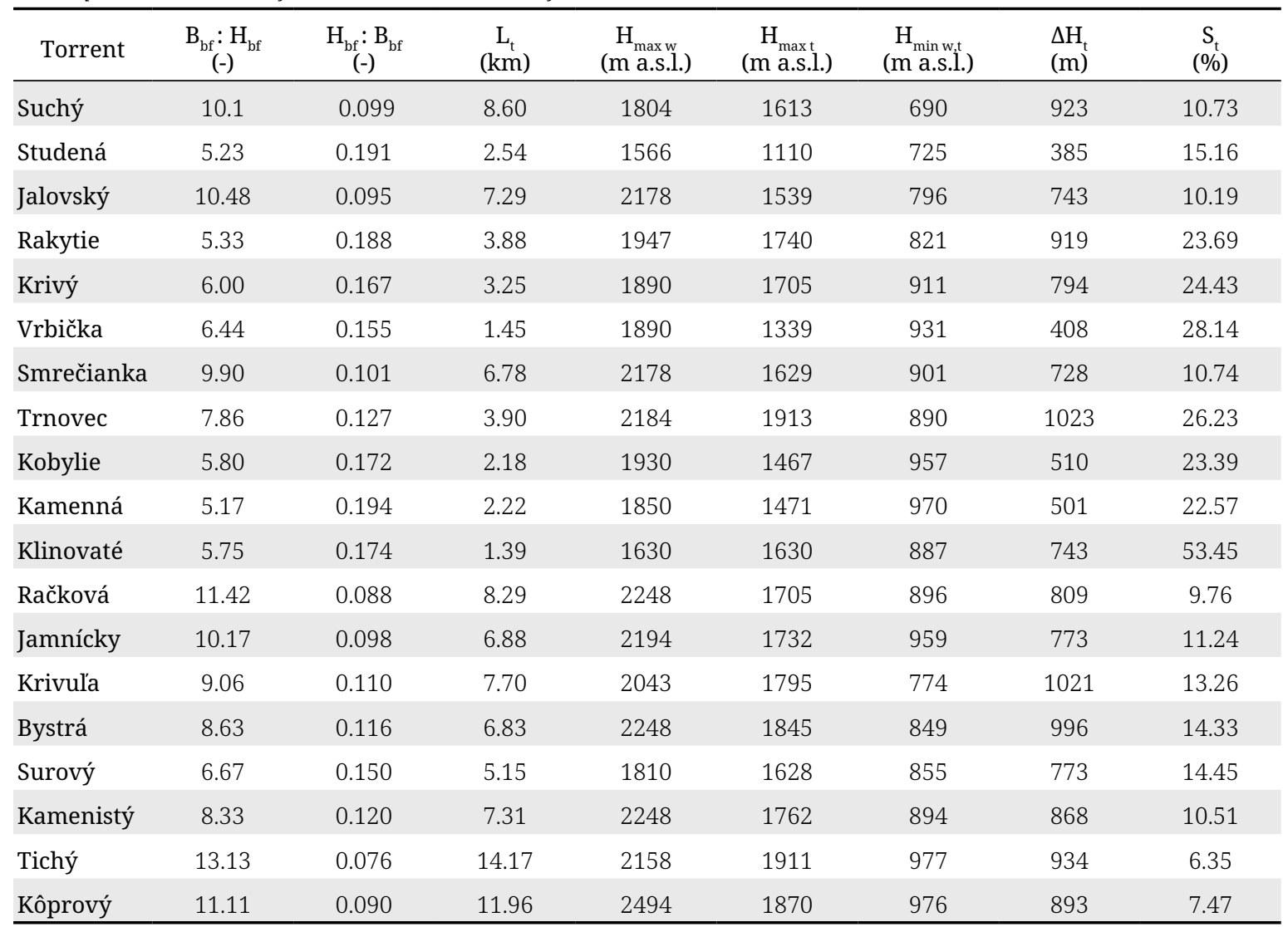

$\mathrm{L}_{\mathrm{t}}$ : length of main stream; $\mathrm{H}_{\max , \mathrm{w}}$ : maximal altitude of the watershed; $\mathrm{H}_{\max \mathrm{t}}:$ maximal altitude of the torrent (spring); $\mathrm{H}_{\text {min } w, t}$ minimal altitude of the watershed and torrent; $\Delta \mathrm{H}_{\mathrm{t}}$ : absolute heigth difference in the watershed; $\mathrm{S}_{t}:$ torrent gradient. 
deviation $s_{d}$ of these differences (Tab. IV). We tested the null hypothesis: $\mathrm{H}_{0}: \mu_{1}-\mu_{2}=0$; the difference is only randomly different from zero. The test criterion is the characteristic:

$t=\frac{\bar{d}}{s_{\bar{d}}}$

and

$S_{\bar{d}}=\frac{S_{d}}{\sqrt{n-1}}$

We accept hypothesis $H_{0}$ if $t \leq t_{\alpha ; f}$ and reject if $t>t_{\text {a:f }}$.

From the detailed results (Tab. IV) it is clear that we reject the null hypothesis $\mathrm{H}_{0}$ in all cases. This means that the differences between the measured characteristics $B_{b f}(m), H_{b f}(m), A_{b f}\left(m^{2}\right)$ and ratios $\mathrm{B}_{\mathrm{bf}}: \mathrm{H}_{\mathrm{bf}}$ and $\mathrm{H}_{\mathrm{bf}}: \mathrm{B}_{\mathrm{bf}}$ and characteristic estimated using the equations of regional hydraulic geometry
III: Derived equations of regional hydraulic geometry

\begin{tabular}{ll}
\hline \multicolumn{1}{c}{ Correlation relation } & \multicolumn{1}{c}{ Regression equation } \\
\hline $\mathrm{B}_{\mathrm{bf}}=\mathrm{f}\left(\mathrm{A}_{\mathrm{w}}\right)$ & $\mathrm{B}_{\mathrm{bf}}=1.8269 \times \mathrm{A}_{\mathrm{w}}^{0.5908}$ \\
$\mathrm{~B}_{\mathrm{bf}}=\mathrm{f}\left(\mathrm{L}_{\mathrm{t}}\right)$ & $\mathrm{B}_{\mathrm{bf}}=1.2405 \times \mathrm{L}_{\mathrm{t}}^{1.0322}$ \\
$\mathrm{~B}_{\mathrm{bf}}=\mathrm{f}\left(\mathrm{H}_{\mathrm{bf}}\right)$ & $\mathrm{B}_{\mathrm{bf}}=9.6027 \times \mathrm{H}_{\mathrm{bf}}^{1.778}$ \\
$\mathrm{H}_{\mathrm{bf}}=\mathrm{f}\left(\mathrm{A}_{\mathrm{w}}\right)$ & $\mathrm{H}_{\mathrm{bf}}=0.3933 \times \mathrm{A}_{\mathrm{w}}^{0.3316}$ \\
$\mathrm{H}_{\mathrm{bf}}=\mathrm{f}\left(\mathrm{L}_{\mathrm{t}}\right)$ & $\mathrm{H}_{\mathrm{bf}}=0.3158 \times \mathrm{L}_{\mathrm{t}}^{0.5794}$ \\
$\mathrm{H}_{\mathrm{bf}}=\mathrm{f}\left(\mathrm{B}_{\mathrm{bf}}\right)$ & $\mathrm{H}_{\mathrm{bf}}=0.2757 \times \mathrm{B}_{\mathrm{bf}}^{0.5689}$ \\
$\mathrm{~A}_{\mathrm{bf}}=\mathrm{f}\left(\mathrm{A}_{\mathrm{w}}\right)$ & $\mathrm{A}_{\mathrm{bf}}=0.5310 \times \mathrm{A}_{\mathrm{w}}^{0.9785}$ \\
$\mathrm{~A}_{\mathrm{bf}}=\mathrm{f}\left(\mathrm{L}_{\mathrm{t}}\right)$ & $\mathrm{A}_{\mathrm{bf}}=0.2997 \times \mathrm{L}_{\mathrm{t}}^{1.6850}$ \\
$\mathrm{~B}_{\mathrm{bf}}: \mathrm{H}_{\mathrm{bf}}=\mathrm{f}\left(\mathrm{A}_{\mathrm{w}}\right)$ & $\mathrm{B}_{\mathrm{bf}}: \mathrm{H}_{\mathrm{bf}}=4.7172 \times \mathrm{A}_{\mathrm{w}}^{0.2535}$ \\
$\mathrm{~B}_{\mathrm{bf}}: \mathrm{H}_{\mathrm{bf}}=\mathrm{f}\left(\mathrm{L}_{\mathrm{t}}\right)$ & $\mathrm{B}_{\mathrm{bf}}: \mathrm{H}_{\mathrm{bf}}=4.1441 \times \mathrm{L}_{\mathrm{t}}^{0.4208}$ \\
$\mathrm{H}_{\mathrm{bf}}: \mathrm{B}_{\mathrm{bf}}=\mathrm{f}\left(\mathrm{A}_{\mathrm{w}}\right)$ & $\mathrm{H}_{\mathrm{bf}}: \mathrm{B}_{\mathrm{bf}}=0.2075 \times \mathrm{A}_{\mathrm{w}}^{-0.2383}$ \\
$\mathrm{H}_{\mathrm{bf}}: \mathrm{B}_{\mathrm{bf}}=\mathrm{f}\left(\mathrm{L}_{\mathrm{t}}\right)$ & $\mathrm{H}_{\mathrm{bf}}: \mathrm{B}_{\mathrm{bf}}=0.2176 \times \mathrm{L}_{\mathrm{t}}^{-0.3385}$ \\
\hline
\end{tabular}

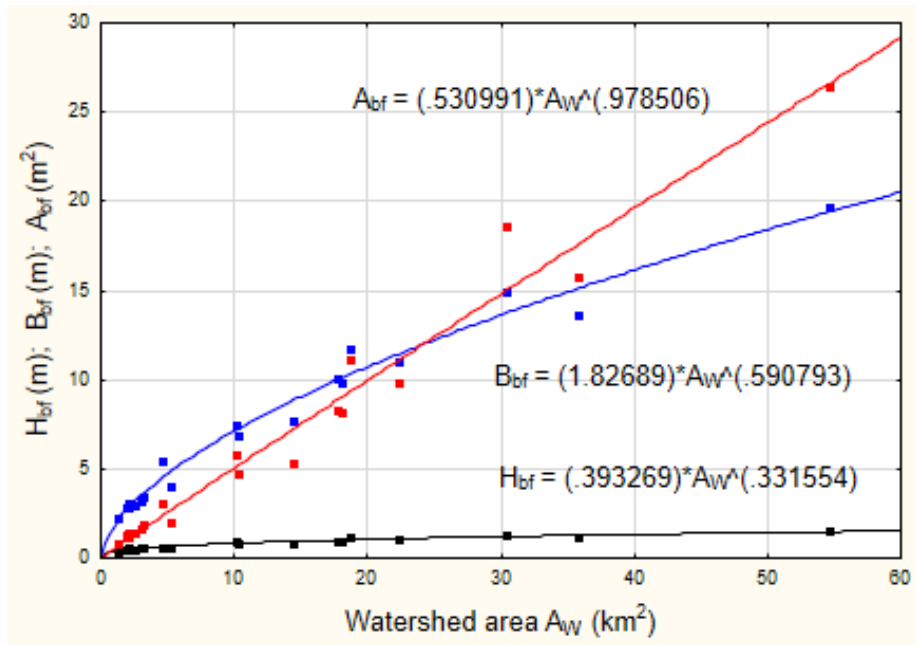

2: Relations between watershed area $A_{w}$ and geometric characteristics of RCS $-B_{b f}, H_{b f}, A_{b f}$

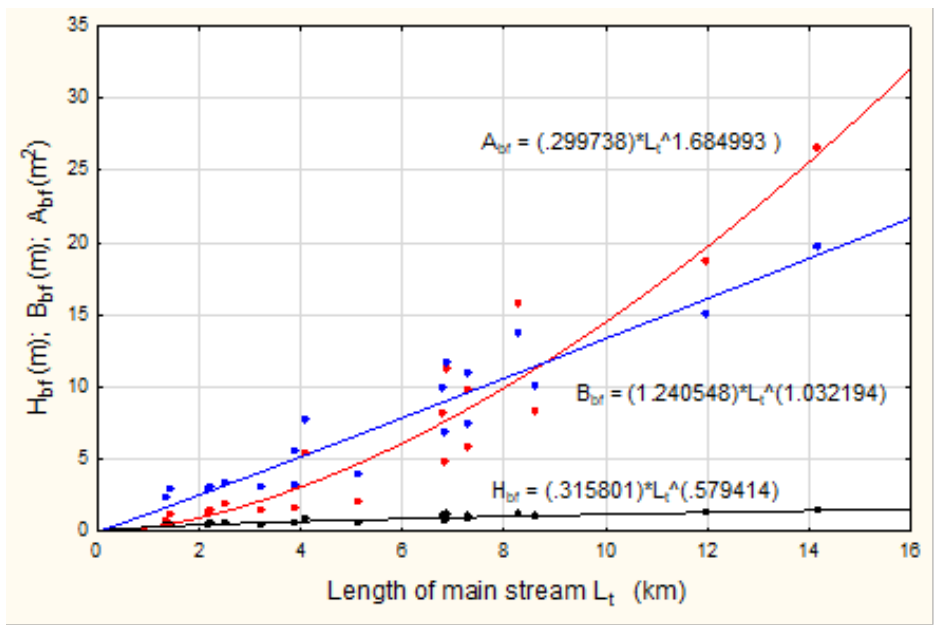

3: Relations between length of main stream $L_{t}$ and geometric characteristics of $R C S-B_{b f}, H_{b f}, A_{b f}$ 


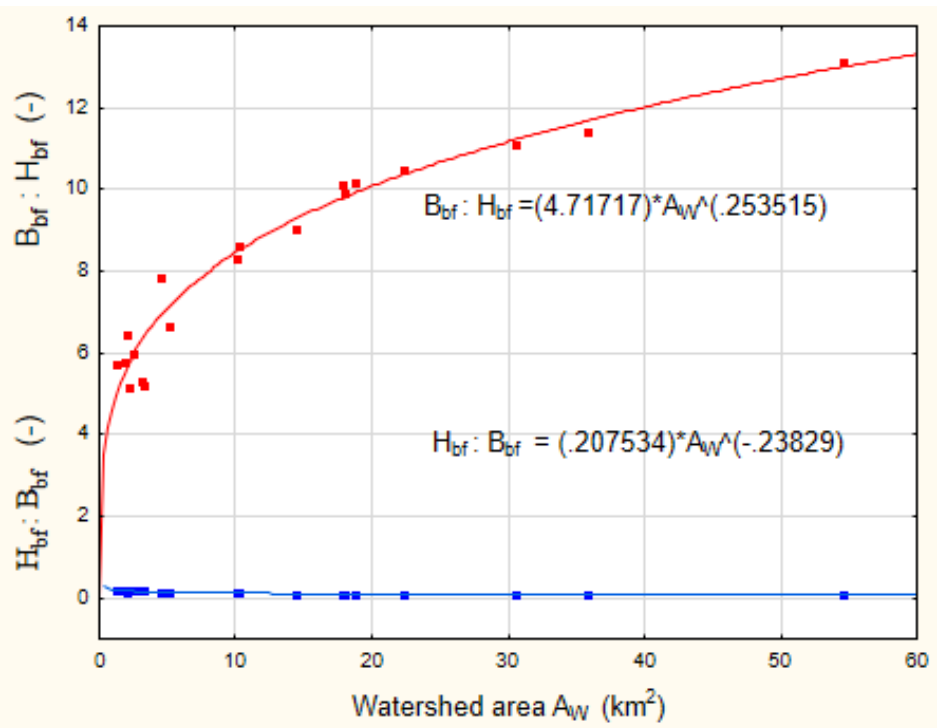

4: Relations between watershed area $A_{w}$ and relations $-B_{b f}: H_{b f}, H_{b f}: B_{b f}$

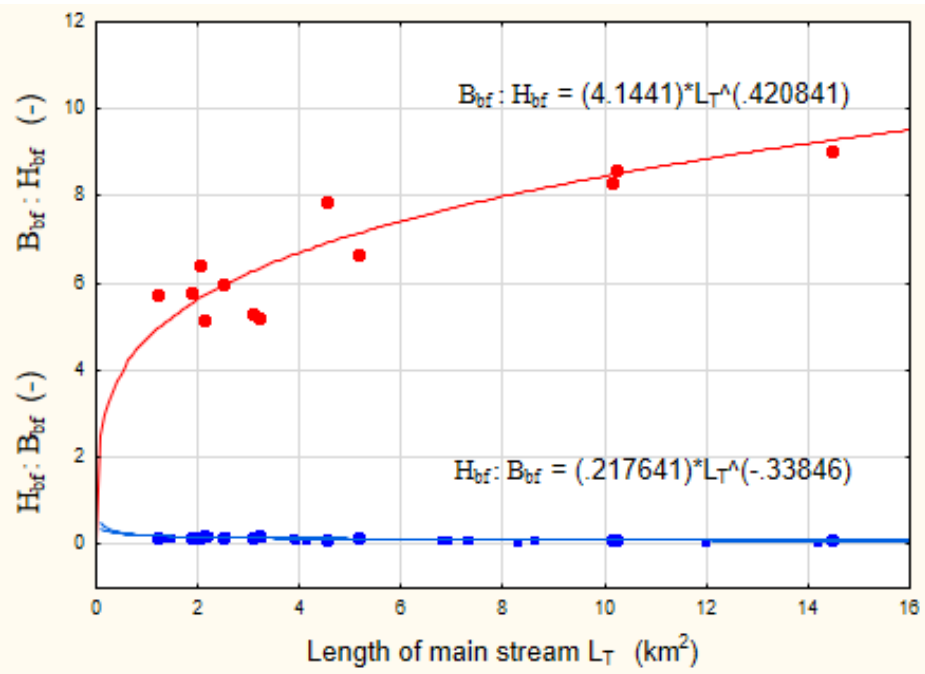

5: Relations between length of main stream $L_{t}$ and relations $B_{b f}: H_{b f}, H_{b f}: B_{b} f$

are found to be significant. Therefore, other factors need to be taken into account when estimating these characteristics, e.g. valley morphology, sediment type, sediment transport regime channel stability, riparian vegetation, etc.

Harman et al. (2008) state that the results from an individual cross-section may not be representative of the geometry of the entire reach nor do can they indicate the degree of local variability along the reach. The authors point out that of the many possible sources of uncertainty in hydraulic observations, two significant groups can be distinguished: sample error and model error. Alexander et al. (2009) state that hydraulic geometry relations assist in an understanding of the channel adjustments process, but are limited in their predictive capabilities and require cautions application when used for such purposes.

Only few authors (Whitbread et al., 2015; Beechie et al., 2007; Thornton et al., 2007; Kemp, 2010) have dealt with the research of the shape characteristics of natural river beds, although this issue is very important from an ecological point of view. A comparison of our results with the those of other authors is given in the Tab. V. We confirmed that estimates of geometric parameters of natural cross-sections, which are based on the equations of regional hydraulic geometry, informative can be used only in the regions from which these equations were derived. 
IV: Statistical characteristic and testing of the results

\begin{tabular}{lcccccccc}
\hline Correlation relation & $\mathrm{R}$ & $\mathrm{R}^{2}$ & $\overline{\mathrm{d}}$ & $\mathrm{S}_{\mathrm{d}}$ & $\mathrm{t}$ & $>=<$ & $\mathrm{t}_{0,01(18)}$ & RMSE \\
\hline $\mathrm{B}_{\mathrm{bf}}=\mathrm{f}\left(\mathrm{A}_{\mathrm{w}}\right)$ & 0.989 & 0.979 & 0.5386 & 0.4657 & 4.872 & $>$ & 2.878 & 0.744 \\
$\mathrm{~B}_{\mathrm{bf}}=\mathrm{f}\left(\mathrm{L}_{\mathrm{t}}\right)$ & 0.944 & 0.890 & 1.3475 & 0.8915 & 6.413 & $>$ & 2.878 & 1.690 \\
$\mathrm{~B}_{\mathrm{bf}}=\mathrm{f}\left(\mathrm{B}_{\mathrm{bf}}\right)$ & 0.992 & 0.984 & 0.5213 & 0.3311 & 6.679 & $>$ & 2.878 & 0.648 \\
$\mathrm{H}_{\mathrm{bf}}=\mathrm{f}\left(\mathrm{A}_{\mathrm{w}}\right)$ & 0.978 & 0.956 & 0.0545 & 0.0372 & 6.214 & $>$ & 2.878 & 0.069 \\
$\mathrm{H}_{\mathrm{bf}}=\mathrm{f}\left(\mathrm{L}_{\mathrm{t}}\right)$ & 0.939 & 0.882 & 0.0902 & 0.0589 & 6.504 & $>$ & 2.878 & 0.113 \\
$\mathrm{H}_{\mathrm{bf}}=\mathrm{f}\left(\mathrm{B}_{\mathrm{bf}}\right)$ & 0.989 & 0.978 & 0.0380 & 0.0269 & 5.996 & $>$ & 2.878 & 0.165 \\
$\mathrm{~A}_{\mathrm{bf}}=\mathrm{f}\left(\mathrm{A}_{\mathrm{w}}\right)$ & 0.985 & 0.969 & 0.8131 & 0.9019 & 7.408 & $>$ & 2.878 & 1.265 \\
$\mathrm{~A}_{\mathrm{bf}}=\mathrm{f}\left(\mathrm{L}_{\mathrm{t}}\right)$ & 0.953 & 0.908 & 1.5473 & 1.4254 & 4.606 & $>$ & 2.878 & 2.197 \\
$\mathrm{~B}_{\mathrm{bf}}: \mathrm{H}_{\mathrm{bf}}=\mathrm{f}\left(\mathrm{A}_{\mathrm{w}}\right)$ & 0.976 & 0.952 & 0.4042 & 0.3411 & 5.027 & $>$ & 2.878 & 0.553 \\
$\mathrm{~B}_{\mathrm{bf}}: \mathrm{H}_{\mathrm{bf}}=\mathrm{f}\left(\mathrm{L}_{\mathrm{t}}\right)$ & 0.898 & 0.806 & 0.9231 & 0.5145 & 7.612 & $>$ & 2.878 & 1.110 \\
$\mathrm{H}_{\mathrm{bf}}: \mathrm{B}_{\mathrm{bf}}=\mathrm{f}\left(\mathrm{A}_{\mathrm{w}}\right)$ & 0.927 & 0.859 & 0.0100 & 0.0107 & 3.966 & $>$ & 2.878 & 0.015 \\
$\mathrm{H}_{\mathrm{bf}}: \mathrm{B}_{\mathrm{bf}}=\mathrm{f}\left(\mathrm{L}_{\mathrm{t}}\right)$ & 0.820 & 0.672 & 0.0185 & 0.0124 & 6.304 & $>$ & 2.878 & 0.023 \\
\hline $\mathrm{RSS}: \mathrm{R}=0 \mathrm{men}$ & & & & & & & $>$
\end{tabular}

RMSE: Root mean square error

$\mathrm{V}$ : Comparison of results with the results of other authors

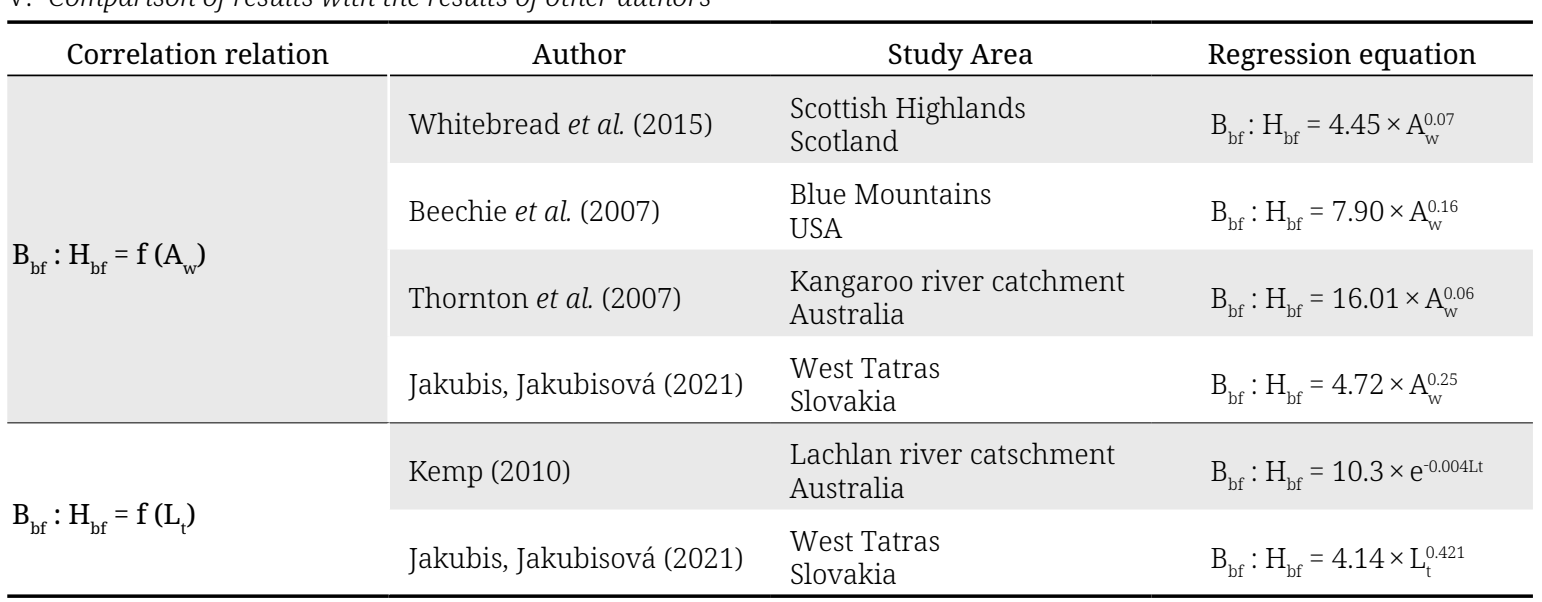

\section{CONCLUSION}

Equations of regional hydraulic geometry were derived for 19 natural torrents of the Western Tatras in the geomorphological unit of the Tatras. We used these data for the analysis of the basic shape (geometric) cross-sections of these torrents. Evaluation of shape characteristics of natural crosssections has more practical uses, the first of which is the acquisition of data for the application of nature-friendly river design and torrent control in the context of both flood and erosion protection of the landscape. Another possibility is the use of these data in the classification of watercourses, as well as in the processes involved in river and land management and watercourses restoration activities, which is considered of impertance, especially in protected areas.

\section{REFERENCES}

AGOURIDIS, C., BROCKMAN, R., WORKMAN, S., ORMSBEE, L. and FOGLE, A. 2011. Bankfull hydraulic geometry relationships for the inner and outer Bluegrass regions of Kentucky. Water, 3(3): 923-948. AISUEBEOGUN, A. O. and EYEKWE, I. C. 2014. Channel dynamics and hydraulics geometry of two tropical deltaic catchments in Southern Nigeria. Landform Analysis, 27: 3-13.

ALEXANDER, J. S., ZELT, R. B. and SCHAEPE, N. J. 2009. Geomorphic segmentation, hydraulic geometry, and hydraulic microhabitats of the Niobrara River, Nebraska-Methods and initial results. Scientific Investigations Report 2009-5008. U.S. Department of the Interior and U.S. Geological Survey. 
ALLEN, G. H., PAVELSKY, T. M., BAREFOOT, E. A., LAMB, M. P., BUTMAN, D, TASHIE, A. and GLEASON, C. J. 2018. Similarity of stream width distributions across headwater systems. Nature Comunications, 9: 610.

BEECHIE, T. J., POLLOCK, M. M. and BAKER, S. 2008. Channel incision, evolution and potential recovery in Walla Walla and Tucanoon River basins, northwestern USA. Earth Processes and Landforms, 33: 784-800.

BISWAS, B. and DAS, B. C. 2016. Hydraulic parameters and morphometric variables interactions in bedrock channel. Questiones Geographicae, 35(3): 75-88.

BUFFINGTON, J. M. and MONTGOMERY, D. R. 2013. Geomorphic classification of rivers. In: SRODER, J. and WOHL, E. (Eds.). Treatise on Geomorphology, Vol. 9, Fluvial Geomorphology. San Diego, CA: Academic Press, pp. 730-767.

DAVID, G. C. L., WOHL, E., YOCHUM, S. E. and BLEDSOE, B. P. 2010. Controls on at-a-station hydraulic geometry in steep headwater streams, Colorado, USA. Earth Surface Processes and Landforms, 35(15): 1820-1837.

FINNEGAN, N. J., ROE, G., MONTGOMERY, D. R. and HALLET, B. 2005. Controls on the channel width of rivers: Implications for modeling fluvial incision of bedrock. Geology, 33(3): 229-232.

HARMAN, C., STEWARDSON, M. and DEROSE, R. 2008. Variability and uncertainity in reach bankfull hydraulic geometry. Journal of Hydrology, 351(1-2): 13-25.

CHOI, M., TAKEMON, Y. and SUMI, T. 2015. Riverbed management by changing reach scale channel configuration. Annuals of Disas. Prev. Res. Inst., No. 58 B. Kyoto: Kyoto University.

JAKUBIS, M. 2000. Runoff characteristics of torrents of the Western Tatras [in Slovak: Odtokové charakteristiky bystrín Západných Tatier]. Zvolen: Technical University in Zvolen.

JAKUBIS, M. and JAKUBISOVÁ, M. 2019. The impact of hydrologic characteristics of mountain watersheds on geometric and hydraulic parameters of natural torrent beds. Journal of Ecological Engineering, 68(5): 841-849.

JAKUBIS, M. and JAKUBISOVÁ, M. 2020. Estimation of basic geometric and hydraulic characteristics of natural torrent beds. Acta Universitatis Agriculturae et Silviculturae Mendelianae Brunensis, 77(5): 841-849.

JULIEN, P. Y. 2014. Downstream hydraulic geometry of alluvial rivers. In Proceedings of the symposium: Sediment Dynamics from the Summit to the Sea. New Orleans, Louisiana: IAHS Publication No. 367.

KEMP, J. 2010. Downstream channel changes on a contracting, anabranching river: The Lachan, southeastern Australia. Geomorphology, 121(3): 231-244.

LATAPIE, A., CAMENEN, B., RODRIGUES, S., PAQUIER, A., BOUCHARD, J. P. and MOATAR, F. 2014. Assessing channel response of a long river influenced by human disturbance. Catenai, 121: 1-12.

MAHMOUDI, M., MAJDZADEH TABATABAI, M. R. and NADOUSHANI MOUSAVI, S. 2019. An analytical approach to the estimation of optimum river channel dimensions. Scientia Iranica, 26(3): 1169-1181.

MILLAR, R. G. 2005. Theoretical regime equations for mobile gravel-bed rivers with stable banks. Geomorphology, 64(3-4): 207-220.

MINISTRY OF ENVIRONMENT OF THE SR. 2002. Landscape Atlas of the Slovak Republic. Bratislava: Ministry of Environment of the SR and Banská Štiavnica: Esprit.

MONTGOMERY, D. R. and BUFFINGTON, J. M. 1997. Channel reach morphology in mountain drainage basins. Geological Society of America Bulletin, 109(5): 596-611.

MONTGOMERY, D. R. and GRAN, K. B. 2001. Downstream variations in the width of bedrock channels. Water Resources Research, 37(6): 1841-1846.

OHARA, N. and YAMATANI, K. 2019. Theoretical stable hydraulic section based on the principle of least action. Scientific Reports, 9: 7957.

OSTERKAMP, W. R., LANE, L. J. and FOSTER, G. R. 1983. An analytical treatment of channel-morphology relations. Geological Survey Professional Paper 1288. Washington: US Coverment Printong Office.

PAGE, K. J. 1988. Bankfull discharge frequency for the Murrumbidgee River, New South Wales. In: WARNER, R. F. (Ed.). Fluvial geomorphology of Australia. Sydney: Academic Press, pp. 267-281.

RICO, M., BENITO, G. and BARNOLAS, A. 2001. Combined paleoflood and rainfall-runoff assessment of mountain floods (Spanish Pirenees). Journal of Hydrology, 245(1-4): 59-72.

ROSGEN, D. L. 1994. A classification of natural rivers. Catena, 22: 169-199.

ROSGEN, D. L. 2009. Watershed assessment of River Stability and Sediment Supply. Fort Collins, Colorado: Wildland Hydrology.

STEWARDSON, M. 2005. Hydraulic geometry of stream reaches. Journal of Hydrology, 306(1-4): 97-111.

THORNTON, E., NEAVE, M. and RAYBURG, S. 2007. Hydraulic geometry in river channel networks as a method for the assessment of river condition. In: WILSON, A. L., DEHAAN, R. L., WATS, R. J., BOWMER, K. H. and CURTIS, A. (Eds.). Proceedings of the $5^{\text {th }}$ Australian Stream Managemen Conference. Australian rivers: making a difference. Thurgoona, New South Wales: Charles Sturt Unoiversity, pp. 401-406. 
VIANELLO, A. and D'AGOSTINO, V. 2007. Bankfull width and morphological units in an alpine stream of the dolomites (Northern Italy). Geomorphology, 83(3-4): 266-281.

WHITEBREAD, H., JANSEN, J., BISHOP, P. and ATTAL. M. 2015. Substrate, sediment, and slope controls on bedrock channel geometry in postglacial streams. Journal of Geophysical Research: Earth Surface, 120(5): 779-798.

Contact information

Matúš Jakubis: jakubis@tuzvo.sk (corresponding author) Mariana Jakubisová: jakubisova@tuzvo.sk 
